TecnoLógicas

ISSN-p 0123-7799

ISSN-e 2256-5337

Vol. 21, No. 42, pp. 111-128

Mayo-agosto de 2018

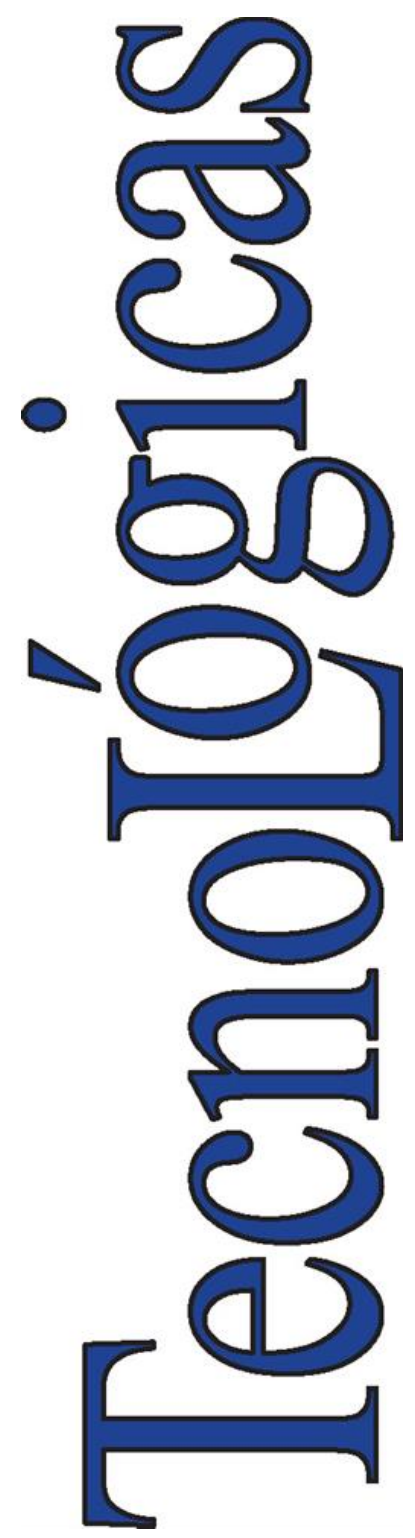

(C) Copyright 2015 por autores y Tecno Lógicas Este trabajo está licenciado bajo una Licencia Internacional Creative Commons Atribución (CC BY)

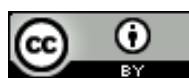

Artículo de Investigación/Research Article

\section{Electricity generation potential from solid waste in three Colombian municipalities}

\section{Potencial de generación de electricidad desde residuos sólidos en tres municipios colombianos}

\author{
Santiago Alzate Arias ${ }^{1}$, Bonie Restrepo-Cuestas ${ }^{2}$ \\ y Álvaro Jaramillo-Duque ${ }^{3}$
}

Recibido: 05 de febrero de 2018

Aceptado: 12 de abril de 2018

Cómo citar / How to cite

S. Álzate Arias, B. Restrepo-Cuestas, y Á. Jaramillo-Duque, Electricity generation potential from solid waste in three Colombian municipalities. TecnoLógicas, vol. 21, no. 42, pp. 111-128, 2018.

\footnotetext{
1 MEng in Industrial Energy Management, Faculty of Engineering, Instituto Tecnológico Metropolitano, Medellín-Colombia, sanalz393@gmail.com

2 MSc in Electrical Engineering, Faculty of Engineering, Instituto Tecnológico Metropolitano, Medellin-Colombia, bonierestrepo@itm.edu.co

$3 \mathrm{PhD}$ in Electrical Engineering, Electrical Engineering Department, Universidad de Antioquia, Medellín-Colombia, alvarojaramillod@udea.com.co
} 


\section{Abstract}

This study estimates the electric energy production potential from municipal solid waste in Colombia. The Colombian municipalities of Pasto (Department of Nariño), Andes (Antioquia) and Guayatá (Boyacá) were selected as representative populations of the national context because of their socioeconomic and demographic features, as well as the public availability of their waste management plans. The technical characteristics of two conversion technologies were analyzed: incineration (thermal conversion) and anaerobic digestion (biological conversion). From a technical point of view, the results showed that anaerobic digestion is feasible in all three scenarios, while incineration is viable in Pasto and Andes.

\section{Keywords}

Municipal solid waste, waste-to-energy, biogas, anaerobic digestion, incineration.

\section{Resumen}

En este trabajo se estimó el potencial de producción de energía eléctrica desde residuos sólidos urbanos. Para lograrlo, se estudiaron dos tecnologías de conversión: incineración (conversión térmica) y digestión anaerobia (conversión biológica). Los municipios colombianos de Pasto (Nariño), Andes (Antioquia) y Guayatá (Boyacá) fueron seleccionados como poblaciones representativas del contexto nacional, debido a sus características socioeconómicas y demográficas, además de la disponibilidad pública de sus planes de gestión de residuos. Los resultados muestran que la incineración es viable en la ciudad de Pasto y Andes, mientras que la digestión anaerobia es posible en los tres escenarios.

\section{Palabras clave}

Residuos sólidos urbanos, residuos a energía, biogás, digestión anaerobia, incineración 


\section{INTRODUCTION}

The world's population is continuously growing. According to the United Nations (UN), by 2040, 9.6 billion people will live on this planet, which represents a $25 \%$ growth over 2014 [1]. Besides, nearly 60\% of the population will be concentrated in urban areas and cities. Although this will result in industrial and economic growth in developing countries, it will also bring about a greater demand for energy and more production of Solid Waste (SW) [2].

Effective waste management has become a world-wide challenge. Cities like Stockholm (Sweden), San Francisco (USA) and Adelaide (Australia) have adopted zero waste policies [3], [4]. They recycle and dispose of their waste in landfills and use it for composting. In Stockholm, a fraction is also incinerated in a controlled manner to obtain heat or electricity.

On the contrary, waste management in other countries is not adequate. In Ghana, for example, SW is incinerated or disposed of in limited outdoor landfills near cities, which brings along public health issues [5].

Another example is Colombia, where more than $85 \%$ of SW is disposed of in an authorized manner (landfills, 81\%; material recovery facilities, $3.09 \%$; and containment buildings, $1.27 \%$ ) [6]. In that country, MSW disposal is part of each municipality's responsibilities, and it should be guided by the municipal Solid Waste Management Plan (SWMP). Such plans should include sorting, storage, treatment, organic matter collection, transportation, characterization (of each type of waste), reuse and final disposal (sanitary landfills) of waste.

However, an important amount of SW is treated adopting unauthorized strategies such as releasing it into bodies of water $(0.45 \%)$ and illegal dumps and containers (14.6\%).

A 2002 analysis showed that the average production of SW in the country was
$0.6 \mathrm{~kg} / \mathrm{inh}$ ab-day. The figures range from 0.3 to $0.9 \mathrm{~kg} /$ inhab-day, depending on the socioeconomic features and size of the population [7].

The energy generation potential from SW produced in Bogotá, Medellín, Cali, Barranquilla and Bucaramanga reached $20.13 \mathrm{GWh} /$ year in 2009 [8]. This potential might be exploited to generate electricity by means of conversion technologies such as incineration, gasification, anaerobic digestion and landfill gas.

In order to promote the use of alternative energy sources, such as solid waste, the Ministry of Mines and Energy of Colombia promulgated Act 1715 in May 2014. It encourages the development and use of Non-Conventional Energy Sources (NCES), especially renewable ones. Furthermore, Section 18 indicates that the energy content of non-reusable or non-recyclable SW is a renewable NCES [9].

This work evaluates the electricity generation potential from solid waste in Colombia. Initially, three municipalities were selected according to two criteria: demographic characteristics (number of inhabitants and rural/urban distribution) and availability of information related to their waste management plan (production and type of waste). The chosen municipalities represent typical urban centers in Colombia.

Afterwards, the possible technologies to convert SW into electricity were evaluated applying technical criteria for each municipality. Finally, the potential of SW to produce energy was calculated using mathematical models and information obtained from the waste management plan of each municipality. This method for waste to energy evaluation can be replicated in municipalities with similar characteristics.

The paper is organized as follows: Section 2 reviews solid waste conversion technologies for electricity generation, including thermal and bioconversion alterna- 
tives. Section 3 describes the method adopted to select the scenarios based on their demographic characteristics and availability of waste management plans. Additionally, appropriate technologies for each scenario as well as the procedure to estimate their energy production potential are established. The selected scenarios and their corresponding energy production potential from suitable technologies are presented in Section 4. Finally, Section 5 draws the most relevant conclusions.

\section{POTENTIAL SW CONVERSION TECHNOLOGIES FOR ELECTRICITY GENERATION}

Two types of technology are commonly used to transform SW into electricity. One of them is thermal conversion, which includes incineration, gasification and pyrolysis. Theoretically, these processes can capture the energy in the waste and transform it into heat, electricity or chemical products for other applications [10]. The other option is bioconversion, where microorganisms decompose waste in the form of solids, sludge or gas. Anaerobic digestion and landfill gas are examples of biological conversion [5]. The following section briefly reviews the SW thermal conversion and bioconversion technologies mentioned above.

\subsection{Incineration}

It is carried out in the range between $750{ }^{\circ} \mathrm{C}$ and $1000{ }^{\circ} \mathrm{C}$ to obtain heat and electricity and these generation processes can be combined [11]. A typical controlled incineration system (electricity and heat) is composed of a waste storage chamber, an incinerator/furnace, a vapor/generator turbine, a fuel-gas cleaning system and a waste treatment system. The calorific value of waste is an important parameter that greatly contributes to the efficiency of the incineration plant [5].

Incineration is a mature technology, used in several developed countries. France, for instance, widely uses incineration: in 2003, 12.6 million tons of nonhazardous waste were treated at 130 incineration plants. A total of $2.9 \mathrm{TWh}$ of electricity were generated, and 9.1 TWh were consumed in the form of heat by private and public users [12].

China actively promotes the production of energy by incineration. In 2014, the country was building 75 plants to process 110,000 tons per day and have a total installed capacity of $2.2 \mathrm{GW}$. Germany has an incineration plant, property of the German Cleaning Company, capable of incinerating 520,000 tons per day and generate $188 \mathrm{kWh}$ of electricity every year [13].

Some studies have evaluated the viability of obtaining energy from incineration in countries like Bangladesh, Nigeria, and KSA (Kingdom of Saudi Arabia) [14]-[16]. In [14], the authors present an overview of energy (electricity) generation potential from solid waste in mega-cities of Bangladesh. In [15], the WTE potential of municipal solid waste (MSW) was assessed throughout Nigeria using the population growth rate factor and the boiler, steam and overall efficiencies for calculating the exploitable energy potential. Other authors [16] evaluated the potential contribution of WTE facilities to the total Saudi peak power demand until 2032 by means of a quantitative analysis of six large cities. In that study, the MSW production rate was assumed to be an average $1.4 \mathrm{~kg} /$ capita/day. To calculate the total energy content per kilogram of municipal waste, the caloric energy content of the various types of waste and MSW contents were considered.

One of the greatest advantages of this process is that it can treat organic and inorganic waste [17]. Therefore, waste volume can be reduced up to $80 \%$. The plant can be continuously fed, and the 
treatment is fast. The complexity of the plant is low; it can be installed in urban areas and meet all the technical and environmental regulations.

One of its drawbacks is that it is not viable to build plants to treat a volume lower than $100 \mathrm{~T}$ of SW per day. In that case, the chemical production of dioxins and slag should be considered. Besides, this technique is not appropriate for SW with high water content [17]-[21].

\subsection{Gasification}

It is the partial combustion of SW and biomass to produce gas and carbon. The resulting gases are mainly $\mathrm{CO}_{2}$ and $\mathrm{H}_{2} \mathrm{O}$, which are reduced to $\mathrm{CO}$ and $\mathrm{H}_{2}$ using coal. An amount of methane and other hydrocarbon gases is produced, depending on the design of the reactor and its operation parameters.

Inside the reactor, heterogeneous reactions transform the raw material into gas in presence of a gasifying reagent. A gasification system is composed of three main elements: the gasifier that produces fuelgas, the cleaning system that removes the hazardous components in the fuel-gas, and the energy recovery system [22].

Large-scale electricity production from SW gasification is not widely documented. In Colombia, there is a small-scale project in the Municipality of Necoclí (Antioquia). It is a $40 \mathrm{~kW}$ generation plant that produces power by gasifying biomass in the form of two-inch wood cubes which, when subjected to high temperatures with a controlled amount of oxygen, produce lean gas that is injected into a conventional enginegenerator [23].

A study conducted in Brazil [24] analyzed and assessed the technical and economic aspects of a MSW gasification configuration for electricity generation. Their technical evaluation was primarily focused on installed power, capacity utilization factor, specific electrical power generation and efficiencies. The economic analysis was carried out based on NPV (Net Present Value) and IRR (Internal Rate of Return). Such study also established a relationship between the amount of electricity obtained from SW gasification and the number of inhabitants in different communities.

The main advantages of gasification are related to the fact that the resulting fuel can be used for different purposes. Additionally, SW volume can be reduced from 50 to $90 \%$ and the plant requires little land to be built; therefore, it can be located in industrial and urban areas.

One of its disadvantages is that the net energy recovery might be low in case of excessive humidity in the waste. Furthermore, the complexity of the process is relatively high [17]-[21].

\subsection{Anaerobic digestion}

Also known as biomethanation, this biological conversion technology transforms organic waste into liquid or gaseous fuels by means of biological reagents [18]. This process involves four stages: hydrolysis, acidification, acetogenesis and methanogenesis. It is carried out in a closed container (biogas digester), where bacteria ferment the organic material under oxygen-free conditions to produce biogas. Such biogas can be used in a boiler or alternative engine [25].

In Brazil, anaerobic digestion has been successful in producing electricity in small scale [26]. In Colombia, Chicón project in Chigorodó (Antioquia) was in its implementation stage in 2016. Such project seeks to produce 2 million $\mathrm{m} 3$ of biogas and $500 \mathrm{~kW}$ of electric power from 15,000 T/year of organic SW [27].

Some authors have evaluated the energy recovery potential of biogas from anaerobic digestion to generate electric or thermal power in Brazil, Tanzania, Algeria, Spain and China [26], [28], [29]. Another work [27] assessed a micro-co-generation 
unit located in a typical Brazilian agroenergy condominium that uses biogas (produced from waste by anaerobic digestion) as renewable fuel. In [28], the authors presented a strategy to utilize organic solid waste from the city of Dar es Salaam (Tanzania) for producing biogas and, ultimately, generating electric energy. This is called the Taka (waste) Gas Project. Additionally, some actions to implement the project and make it feasible are discussed. Regarding Asia, an analysis of the sustainability of current anaerobic digestion methods in China was introduced in [29]. On the other hand, in [30] the authors focus on the conversion of municipal solid waste to biogas as a local energy supply in urban areas. Three urban models were identified along with a matrix of the typical Organic Fraction of Municipal Solid Waste (OFMSW). In order to analyze energy generation, theoretical production and substrate composition are calculated.

Anaerobic Digestion is profitable and applicable to a production greater than 2 T/day of SW. However, the plant must only be fed the organic fraction, which means waste sorting is necessary. Nevertheless, the process avoids the release of greenhouse gases, its digestate is rich in nutrients and it can be used as organic fertilizer. Additionally, in small-scale plants, the co-digestion of the raw material or SW can be carried out with biosolids. In general, the resulting biogas must be treated for final use. Besides, the complexity of this type of plants is low and they are usually located in rural areas [17]-[21].

\subsection{Landfill gas}

The decomposition of organic waste in garbage dumps is slightly similar to anaerobic digestion in biogas digesters. Microorganisms living in the organic material, such as residues of food and paper, cause decomposition as well as methane and carbon dioxide release. Landfill gas (LFG) is usually $50 \%$ methane and $50 \%$ carbon dioxide. Such biogas released by the dumps is gathered and burned to produce electricity. Generally, it is collected by pipes that reach the wells installed inside the landfills [5].

This technology has been successfully applied in countries like Brazil, where a potential of $660 \mathrm{MW}$ from landfills was estimated in 2009. In fact, in 2014, $69 \mathrm{MW}$ were produced from biogas recovered from landfills in São Paulo (11,244,369 inhabitants), Belo Horizonte $(2,375,444)$, Salvador $(2,676,606)$ and Uberlândia $(619,536)$ [31]. Some studies have evaluated the electricity generation potential of landfill biogas [32][36]. In [32], the authors estimated the feasibility of LFG in a trigeneration scheme in Hong Kong. In [33], the authors investigated the potential for economically viable electricity generation by means of energy recovery from landfill biogas in Brazil. Moreover, in [34], the authors proposed to feed the national grid with a MSW power plant. In [35], the author presented a feasibility analysis of landfill gas recovery in Mexico. In [36], the authors evaluated the renewable energy potential of MSW and the environmental benefits of carbon reduction in Bangladesh using WTE strategies for urban waste management. The energy potential of different WTE strategies is assessed using a standard energy conversion model and a greenhouse gas (GHG) emissions model. The evaluation was conducted using a first-order decay model. Many of the works above employed the tool LandGEM to evaluate energy production potential.

Producing landfill biogas is a low-cost alternative to generate electric or thermal energy. However, its efficiency is limited to 30 or $40 \%$ of the generated gas. Since the natural resources are returned to the soil, swamps might become useful areas. The level of complexity of this kind of plants is low; for that reason, their operation does not require qualified staff. It also presents 
some disadvantages: it requires large areas to be operated, spontaneous combustion might occur as a result of the accumulation of methane gas, and surface runoff during rains causes the soil and groundwater to be contaminated with lixiviates [17]-[21].

To determine the most suitable technology for each scenario, some aspects should be considered: number of inhabitants, per capita waste production, and waste composition. The following section is a description of the method to select the study cases. Besides, it elaborates on how to select, form a technical point of view, the appropriate conversion technology for each case under analysis. For that purpose, the main advantages and disadvantages of such technologies are included.

\section{MATERIALS AND METHODS}

This work was divided into two stages. First, three Colombian population scenarios were selected based on the availability of their waste management plans and demographic characteristics, such as ruralurban population. Second, the appropriate technologies for each scenario and the procedure to estimate energy production potential were established.

\subsection{Selection of scenarios}

To evaluate energy production, three cases were chosen in line with Law 388 of 1997 for Land-use Planning [37]. Section 9 therein defines the plans to be adopted by three groups [38]: Group $1\left(\mathrm{G}_{1}\right)$, municipalities with less than 30,000 inhabitants; Group $2\left(\mathrm{G}_{2}\right)$, municipalities with a population between 30,000 and 100,000; and Group $3\left(\mathrm{G}_{3}\right)$, more than 100,000 inhabitants.

The population forecast for 2015 to 2020 is based on information obtained from the 2005 census (DANE) [40].
To select one municipality per group, the rural/urban ratio (Urban Population UP) of each population was evaluated. Regarding this parameter, a trend was found in each group: $G_{1}$, predominantly rural population (UP>1); $\mathrm{G}_{2}$, balanced rural and urban population $(0.9<\mathrm{UP}<1.1)$; and $\mathrm{G}_{3}$, predominantly urban population $(\mathrm{UP}<1)$.

This classification allows to consider only the municipalities that exhibit said characteristic in each group. Also, it enables to analyze three scenarios with different waste production scales and composition. Consequently, the range of possible conversion technologies for each scenario may vary.

Another selection criterion was the availability of the Urban Solid Waste Management Plans (SWMPs). The municipalities that had not yet developed their SWMP or whose documentation was not publicly accessible were discarded. Besides, if a municipality did not provide sufficient information (physical composition, mass fraction, quantity and features), it was not included.

\subsection{Selecting a conversion technology for each scenario}

The information in the SWMPs regarding the amount, physical composition and per capita generation of solid waste was analyzed. By pondering the main advantages and disadvantages of both technologies, it was possible to recommend the most appropriate option (from a technical standpoint) in the three scenarios.

Energy recovery potential (ERP) was calculated following the mathematical models in Section 3.3. They are based on the efficiency of the technology, as well as the mass and the lower calorific value (LCV) of the SW [40], [41]. The mass depends on per capita generation, which is determined by the number of inhabitants in different population scenarios. The mod- 
el used in [40] for incineration, and given in (1), depends on the LCV of the total generated organic and inorganic SW. The authors in [42] used model (2) for anaerobic digestion. Such model depends on the LCV of methane, the principal component of biogas derived from the fermentation of organic waste. Finally, incineration and anaerobic digestion were recommended, as described in Section 4.2.

Lower Calorific Value (LCV) of waste: The ERP from incineration depends on the LCV of the total waste. After the physical composition of the SW of each scenario is established, the total LCV can be estimated with the weighted LCV per kind of waste and its mass fraction.

The typical LCV of each component of SW was taken from the Guidebook for the application of waste to energy technologies in Latin America and the Caribbean [43]. Such document presents study cases in Buenos Aires (Argentina), Toluca (Mexico) and Valparaíso (Chile), and it suggests that the MSW in these regions presents a similar physical composition [44].

The LCV of each type of waste was compared to other studies conducted in Saudi Arabia and Spain. At the domestic level, they were also contrasted with the LCVs obtained from the chemical characterization by Empresas Varias de Medellín (EEVVM) in 2009 [45]. Those LCVs are presented in Table 1. In this study, the LCVs from Buenos Aires, Toluca and Valparaíso were used for the calculations of the selected scenarios. Table 1 shows that the values reported by EEVVM are even higher to those used in [44]. Consequently, the estimate was made with values below those reported by EEVVM, which reduces uncertainty in the calculation of the ERP.

\subsection{Mathematical models for ERP calculation}

Incineration: Equation (1) is the expression to calculate the amount electricity that can be obtained from incineration [41]. An 18\% efficiency was applied in this case [45]:

$$
E R P_{i}=\eta\left(\mathrm{M} . L C V_{M S W}\right) / 1000
$$

where

ERP $\quad$ Energy Recovery Potential from incineration [MWh/day];

$M \quad$ Total mass of dry solid waste

$L C V_{M S W} \quad$ Lower Calorific Value of the Waste $[\mathrm{kWh} / \mathrm{Kg}]$;

$\eta \quad$ Total process efficiency.

Anaerobic digestion: This is the preferred process for the organic fraction of MSW, which allows the activity of microbes in presence of humidity. The expression for calculating the electricity generation potential of the total organic fraction of the MSW is given in (2). The efficiency of the process was $26 \%$, which corresponds to a reciprocating internal combustion engine in the literature [42]:

\begin{tabular}{ccccc} 
& \multicolumn{2}{c}{ Table 1. LCV (MJ/kg) reference values per type of waste. Source: Authors. } \\
\hline Type of waste & Saudi Arabia [41] & $\begin{array}{c}\text { Argentina } \\
\text { Chile } \\
\text { Mexico [44] }\end{array}$ & EEVVM [46] & $\begin{array}{c}\text { Spain } \\
{[43]}\end{array}$ \\
\hline $\begin{array}{c}\text { Paper and } \\
\text { cardboard } \\
\text { Assorted } \\
\text { foods }\end{array}$ & 15.82 & 15.6 & 23.23 & 10.05 \\
$\begin{array}{c}\text { Assorted } \\
\text { plastics }\end{array}$ & 5.58 & 4.6 & 6.97 & 2.72 \\
$\begin{array}{c}\text { Fabrics } \\
\text { Wood }\end{array}$ & 32.56 & 32.4 & 37.17 & 35.22 \\
\hline
\end{tabular}




$$
E R P_{A . D .}=\sum_{i=1}^{n} P . W_{P C} . f . M_{O F S W} \cdot Q . \eta
$$

where

$\begin{array}{ll}P & \begin{array}{l}\text { Population residing at a } \\ \text { specific place [inhab]; }\end{array} \\ W P C & \begin{array}{l}\text { Annual waste generation } \\ \text { per capita [T/inhab-day]; }\end{array} \\ f & \begin{array}{l}\text { Organic matter fraction in } \\ \text { solid waste [\%]; }\end{array} \\ \text { MoFSW } & \begin{array}{l}\text { Generation of methane per } \\ \left.\text { ton of OFSW [Nm }{ }^{3} / \mathrm{T}\right] ;\end{array} \\ & \\ & \begin{array}{l}\text { Lower Calorific Value of } \\ \text { biogas due to methane } \\ {\left[\mathrm{MJ} / \mathrm{m}^{3}\right] .}\end{array}\end{array}$

Although anaerobic digestion is carried out under controlled operation conditions, different values of methane generated from the OFSW have been reported. For the present study, $71 \mathrm{Nm}^{3} / \mathrm{T}$ was selected, assuming a $55.5 \%$ methane in the biogas [46]. The literature reports biogas performance values from 67.5 to $122 \mathrm{Nm}^{3} / \mathrm{T}$ of organic fraction of waste [42].

\section{RESULTS AND DISCUSSION}

The results will be explained in accordance with the methods in Section 3. At the beginning, Colombian towns were classified into three groups. Subsequently, considering the demographic features and the availability of their waste management plans, a representative example was chosen from each group to be the study case. After the physical composition and mass fraction of the MSW were analyzed, the energy generation potential of each viable technology in the three scenarios was estimated.

\subsection{Analysis of the population}

The results obtained with the methods described above suggest selecting a scenario for each group $\left(\mathrm{G}_{1}, \mathrm{G}_{2}\right.$ and $\left.\mathrm{G}_{3}\right)$. In Colombia, $78 \%$ of the municipalities are in $\mathrm{G}_{1}$; $16.4 \%$, in $\mathrm{G}_{2}$; and the remaining $5.6 \%$, in $\mathrm{G}_{3}$. The population projections for the selected scenarios were taken from the census conducted by the National Statistics Office (Departamento Nacional de Estadísticas, DANE); they are available until 2020 only.

Scenario 1: $\mathrm{G}_{1}$ is composed of $870 \mathrm{mu}-$ nicipalities with less than 30,000 inhabitants. The analysis of this group revealed that $52 \%$ of the municipalities in it (470) have less than 10,000 inhabitants. Therefore, the scope was narrowed down to those 470 municipalities. Subsequently, the UP was evaluated as explained in Section 3. In this group, such index exceeded 1 (predominantly rural); thus the search was reduced to 357 municipalities.

Later, the municipalities of Guayatá, Pinchote and Villa Caro were found to report sufficient information on the characteristics of their SW production in their SWMPs. Therefore, they were preliminarily selected for the evaluation. A detailed revision of the information revealed that Guayatá (UP = 2.94) has a complete SWMP; therefore, it was finally selected as the scenario for $\mathrm{G}_{1}$ [47].

Fig. 1 shows the projected population of Guayatá for the 2015-2020 period; the rural and urban proportions are differentiated. A slight decrease in both populations can be observed during that period, but it is more noticeable in the rural group. By 2020, the UP will be 2.69. Therefore, Guayatá will maintain its urban-rural ratio over 1.

Scenario 2: $\mathrm{G}_{2}$ is composed of $183 \mathrm{mu}-$ nicipalities. Most of them are concentrated in the range between 30,000 and 50,000 inhabitants (117 municipalities). Out of these, 15 present a UP between 0.9 and 1.1 
(i.e., a proportional relationship between rural and urban population).

In this group, official information was only found for the Municipality of Andes. Their waste management plan describes the physical composition, mass fraction and SW generated per capita [48]. Andes' UP is 1.02 . By 2020 , this figure will come down to 0.96. This decrease indicates a more significant growth of the urban area.

The demographic growth in Andes projected for the 2015-2020 period is shown in Fig. 2. Although the urban population is expected to grow significantly (almost 1,700 inhabitants), the rural share will stay steady with about 220 new inhabitants. This is a positive indicator because the projections of production of solid waste (therefore, electric energy) rise.

Scenario 3: $\mathrm{G}_{3}$ is composed of 62 municipalities. Out of these, 60 present a UP below 1 (predominantly urban). Most populations in this group were found to be in the range bet ween 100,000 and one million inhabitants.

In this subgroup, the required information on physical composition, mass fraction and SW generated per capita was obtained from the Municipalities of Pasto and Pereira. Finally Pasto, with a 0.2 UP, was chosen because it had a complete SWMP [50]. The other municipalities with a UP below 1 provided little information or, in many cases, their SWMP was not officially published.

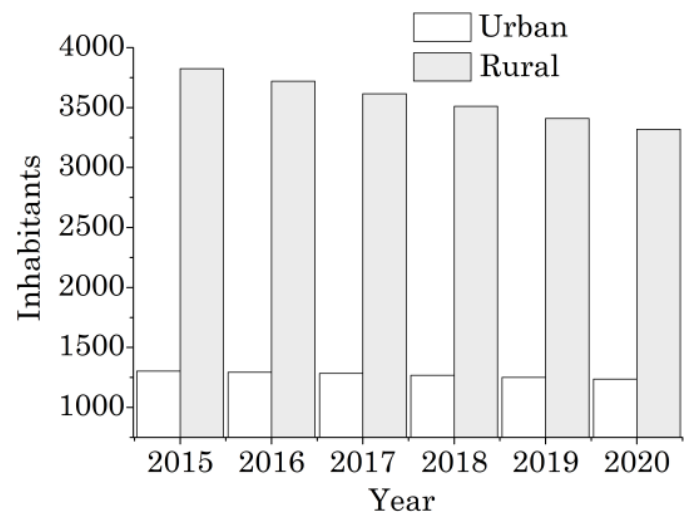

Fig. 1. Population of Guayatá projected for the 2015-2020 period. Source: Authors.

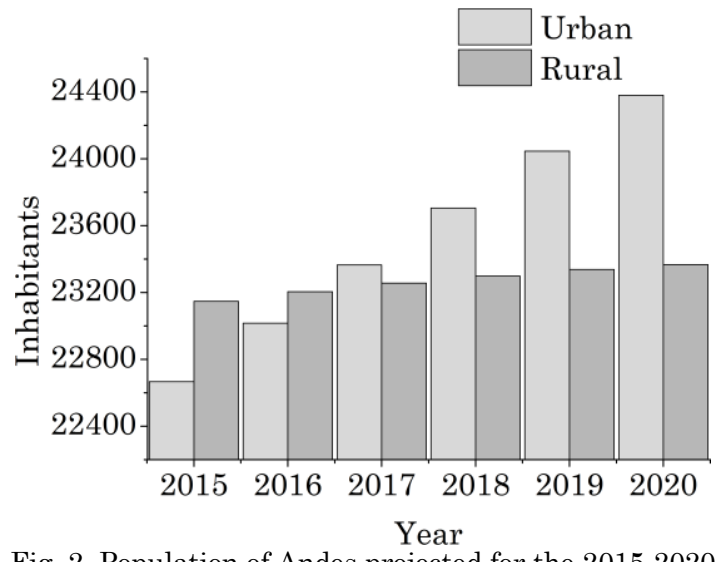

Fig. 2. Population of Andes projected for the 2015-2020 period. Source: Authors.

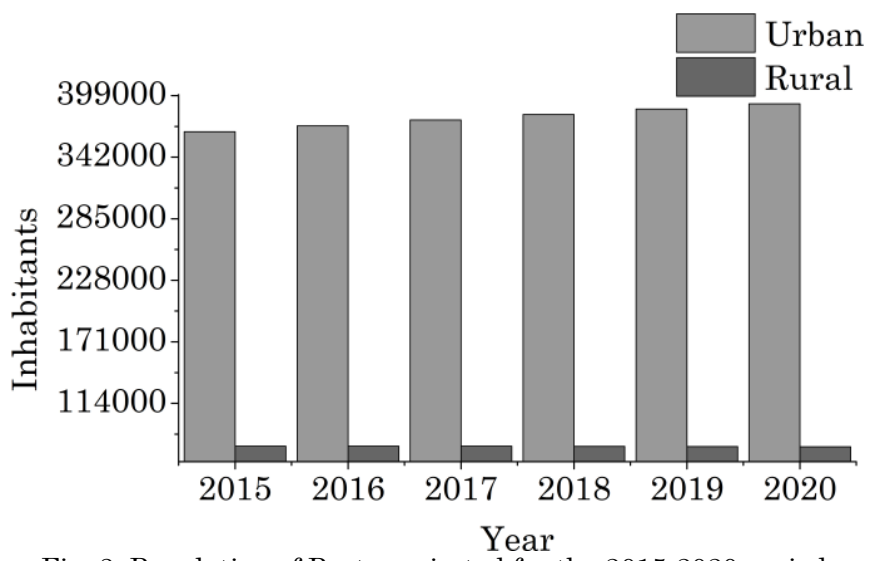

Fig. 3. Population of Pasto projected for the 2015-2020 period. Source: Authors. 


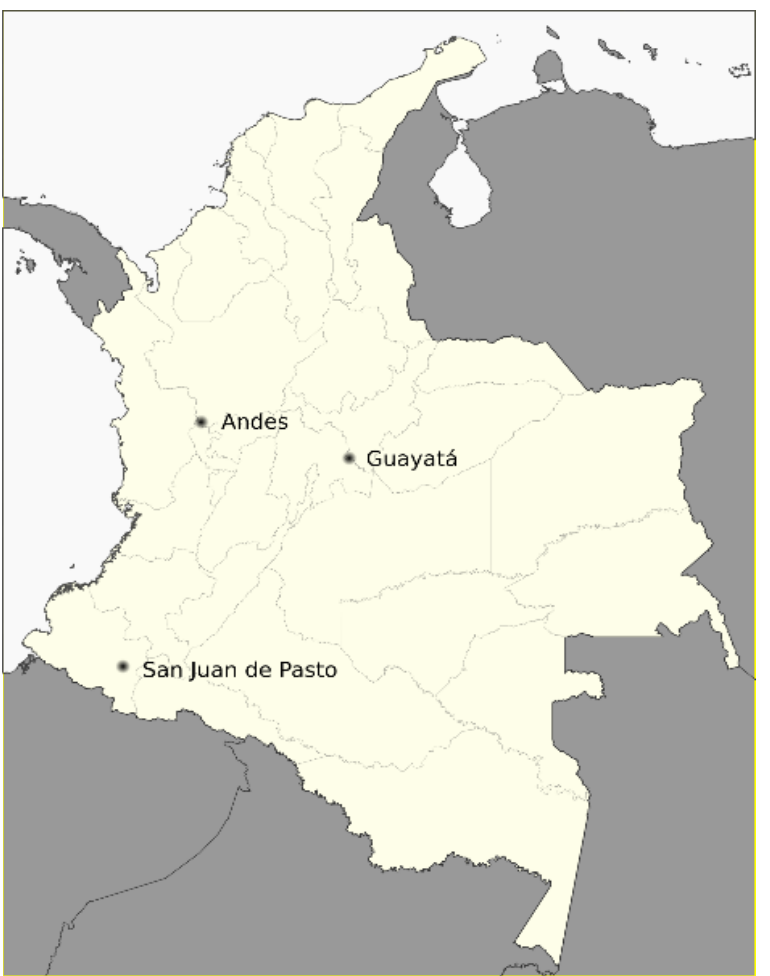

Fig. 4. Geographic location of the municipalities selected as Scenarios for groups $\mathrm{G}_{1}$ (Guayatá), $\mathrm{G}_{2}$ (Andes) and $\mathrm{G}_{3}$ (Pasto). Source: Authors.

The demographic growth in Pasto projected for the 2015-2020 period is shown in Fig. 3. This municipality presents an increase of about 26,000 inhabitants in the urban area. In contrast, the rural component does not exhibit a significant expansion; this is, its rural population remains constant. By 2020, their UP will be 0.19 , which indicates a slight growth of the urban area.

Fig. 4 shows the geographic location of Guayatá, Andes and Pasto (Scenarios 1, 2 and 3 , respectively) in the map of Colombia.

$L C V$ of waste: Based on the physical composition of the SW, the total LCV can be estimated from the weighted LCV of the mass fractions of each type of waste. The typical LCV of each component of the SW (reference LCV) was taken from the Guidebook for the application of waste to energy technologies in Latin America and the Caribbean [43], [44]. The composition and LCV of the waste generated in the three scenarios can be observed in Table 2 .
The recoverable fraction and per capita waste generation reported in their solid waste management plans can be observed in Table 3. The Municipalities of Pasto and Andes lack per capita production indicators for rural areas. In the waste management plans of Guayatá, Sabaneta and Medellín, these values are $0.3,0.28$ and 0.27 $\mathrm{kg} /$ inhab-day, respectively. Since these numbers are similar in municipalities with different populations, the average among the reported values was taken: 0.28 .

\subsection{Selection of solid waste to energy con- version technologies}

This section presents the selection of the most adequate technology for each scenario. In general, incineration (thermal conversion) and anaerobic digestion (bioconversion) were found to be the most appropriate options considering their advantages and disadvantages. 
Electricity generation potential from solid waste in three Colombian municipalities

Table 2. Total LCV, Reference LCV and MF in three scenarios. Source: Authors.

\begin{tabular}{lcccc} 
& \multirow{2}{*}{$\begin{array}{c}\text { Reference LCV } \\
{[\mathrm{MJ} / \mathrm{kg}][44]}\end{array}$} & Guayatá[48] & Andes [49] & Pasto [50] \\
\cline { 3 - 5 } & 15.6 & 12.4 & 7.94 & 8.31 \\
Paper and cardboard & 4.6 & 51.4 & 60.7 & 70 \\
Assorted food waste & 32.4 & 12.7 & 2.16 & 8.57 \\
Assorted plastics & 18.4 & 0.7 & - & 1.41 \\
Fabrics & 15.4 & 1.2 & - & 0.73 \\
Wood & Total LCV & $\mathbf{8 . 7 3}$ & $\mathbf{4 . 7 3}$ & $\mathbf{7 . 6 6}$ \\
\hline
\end{tabular}

Table 3. Per capita waste generation [kg/inhab-day] in each scenario. Source: Authors.

\begin{tabular}{lccc}
\hline & Guayatá & Andes & Pasto \\
\hline Urban & 0.48 & 0.48 & 0.55 \\
Rural & 0.30 & 0.28 & 0.28 \\
$\begin{array}{l}\text { Recoverable } \\
\text { mass [\%] }\end{array}$ & 78.40 & 70.81 & 89.02 \\
\hline
\end{tabular}

Thermal conversion:

Since gasification has rarely been implemented for processing MSW at the international level and due to its complexity, it was not taken into account in this evaluation.

Incineration is a widely used technology in SW urban processing and its level of complexity is low. As a result, it was considered to be applicable to all three scenarios.

However, inconveniences arise from incineration when it is applied to Scenario 1 Guayatá $(5,126$ inhabitants) because of its low total waste production (1.74 T/day). Furthermore, the operating and maintenance costs are high for a small power station of this type [20].

Nevertheless, it is applicable to Andes and Pasto, which have 45,184 and 440,040 inhabitants, respectively. Currently, these municipalities produce 17.62 and $225 \mathrm{~T}$ of waste/day. The study in [19] revealed that, above $100 \mathrm{~T} /$ day, incineration can be implemented by means of a circulating fluidized bed. This technology is already being commercialized and can be adapted to SW with low calorific value.

Based on the above, we can conclude that incineration is an alternative for municipalities in $\mathrm{G}_{2}$ and $\mathrm{G}_{3}$. However, there might be issues with technology transfer- ence and scalability in Guayatá (G1). The daily waste production capacity in that population is way below the one reported by other processes worldwide [19], [50][53]. Although Andes produces a low amount of waste with 45,184 inhabitants, its population and waste generation are expected to grow.

Biological conversion technologies: Even though landfill gas offers advantages such as the low cost of investment and collected waste, the latter must be properly stored and covered, thus generating additional expenses [24]. Besides, the generated biogas' recovery rate might be less efficient, as in the case of anaerobic digestion [54].

Anaerobic digestion was selected because it is carried out under controlled temperature, humidity, $\mathrm{pH}$ and oxygenfree conditions, in digester tanks [25].

This technology is applicable to the three scenarios because the produced waste is organic (see Table 2). In addition, there are other well-known technologies that can be implemented to generate electric energy on a small scale $(30 \mathrm{~kW})$ [55]. Anaerobic digestion offers positive environmental benefits, such as controlling the emission of greenhouse gases.

In conclusion, anaerobic digestion is technically viable for the three communities under study because it can be imple- 
mented on small and large scales. This fact facilitates its acquisition for producing electrical energy.

\subsection{Estimation of energy recovery potential}

Once the technologies were selected for each scenario, the electrical energy potential that can be recovered from them was estimated. The results are presented below.

Incineration: To estimate the ERP from incineration, the LCVs of the SW generated in Scenarios 2 and 3 were calculated (iError! No se encuentra el origen de la referencia.). Furthermore, the LCVs reported in [44] were considered for each type of waste. Such LCVs have been employed in studies on other cities in Latin America, as mentioned in Section 4.1.
Most waste is organic biodegradable material, followed by plastics or paper and cardboard. Fig. 5 presents the daily electrical energy production from incineration in Andes, which applies the model described in Equation (1). It can be observed that, by 2020, up to $4.34 \mathrm{MWh} /$ day might be obtained.

Fig. 6 shows the electrical energy production in Pasto based on the same model. It can be seen that, by 2020 , it would be possible to recover $90.41 \mathrm{MWh} /$ day. This city has a greater energy recovery potential because of its larger population. Energy production is directly proportional to the number of inhabitants, and it increases or decreases according to the projected population growth.

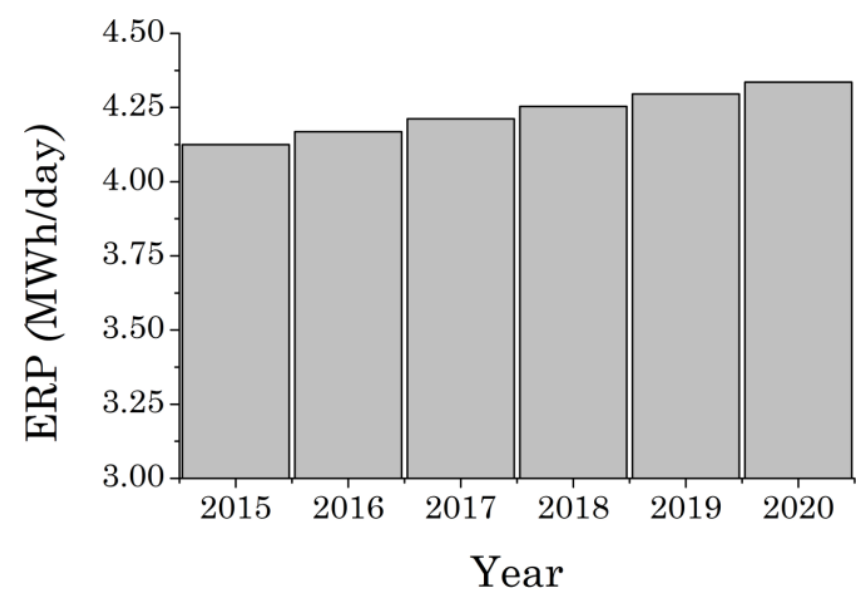

Fig. 5. Electrical energy production from incineration in Andes. Source: Authors.

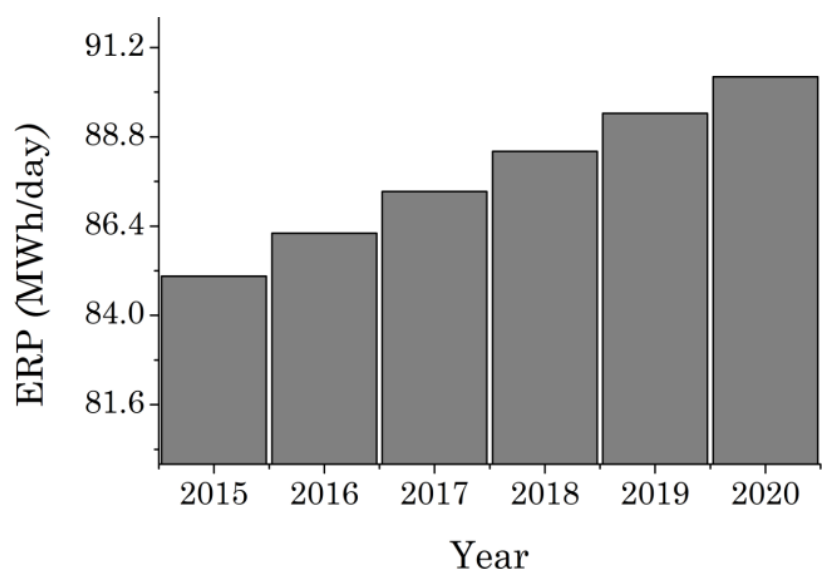


Fig. 6. Electrical energy production from incineration in Pasto. Source: Authors.

In the case of Guayatá, the energy production potential from incineration was not evaluated (Section 4.2).

Anaerobic digestion: Figures 7, 8 and 9 detail the projections of electrical energy generated from anaerobic digestion for the 2015-2020 period. Generation in the Municipality of Guayatá will be low and range between 0.12 and $0.14 \mathrm{MWh} /$ day during the 2015-2020 period, as it can be seen in Fig. 7.

Fig. 8 and 9 suggest that, by 2020, energy generation in Andes and Pasto will increase every year up to 1.23 and 18.25 $\mathrm{MWh} /$ day, respectively.

The LCV of the biogas used to evaluate the mathematical models was $5.97 \mathrm{kWh} / \mathrm{m}^{3}$ $\left(21,51 \mathrm{MJ} / \mathrm{m}^{3}\right)$, which corresponds to the study by [56] (See Section 3.3).
Based on these results, by 2020 , a total $2,829,000 \mathrm{kWh} /$ month would be obtained from incineration in Pasto and Andes. If a four-person household is assumed to consume $145 \mathrm{KWh} /$ month, the average demand of 19,510 households could be met.

On the other hand, if energy was obtained from anaerobic digestion, a total $579,000 \mathrm{kWh} /$ month could be recovered in the three communities. This supply could satisfy the average demand of 3,900 4person households.

These estimates can illustrate the potential and impact of waste to energy technologies on such municipalities. Additionally, environmental and waste management benefits should be considered before evaluating this type of technologies.

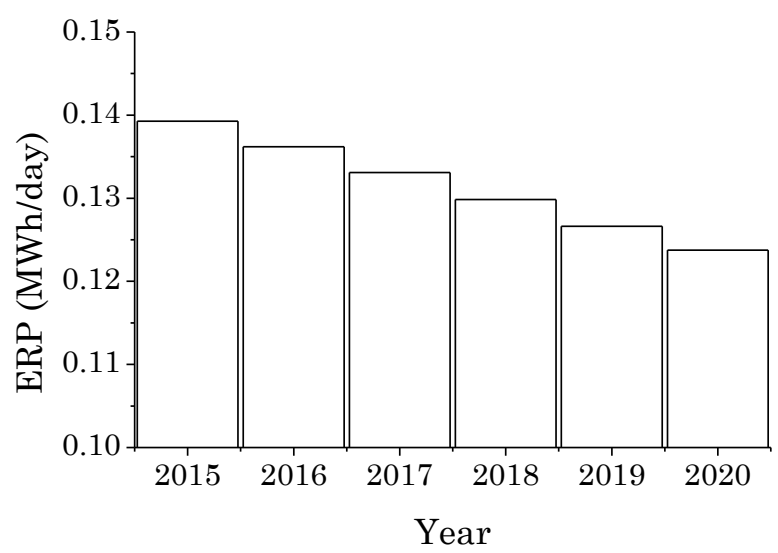

Fig, 7. Electrical energy production from anaerobic digestion in Guayatá. Source: Authors. 


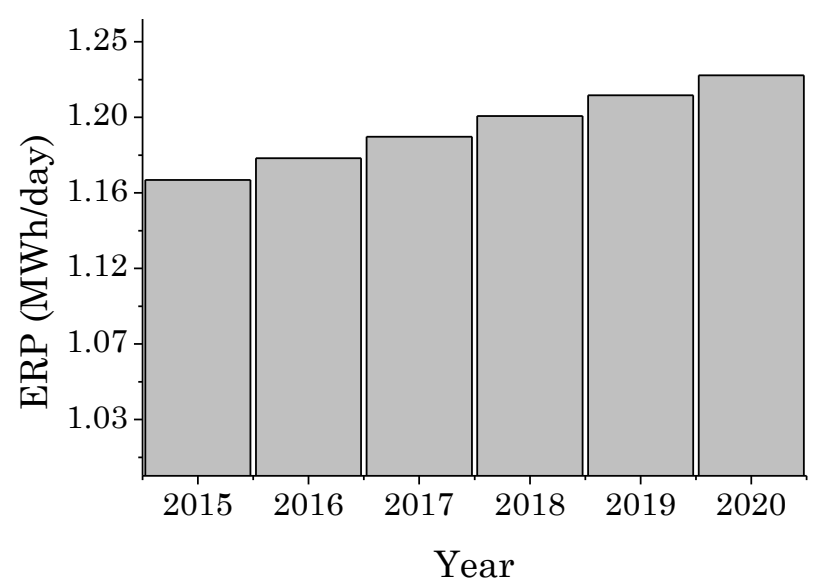

Fig. 8. Electrical energy production from anaerobic digestion in Andes. Source: Authors.

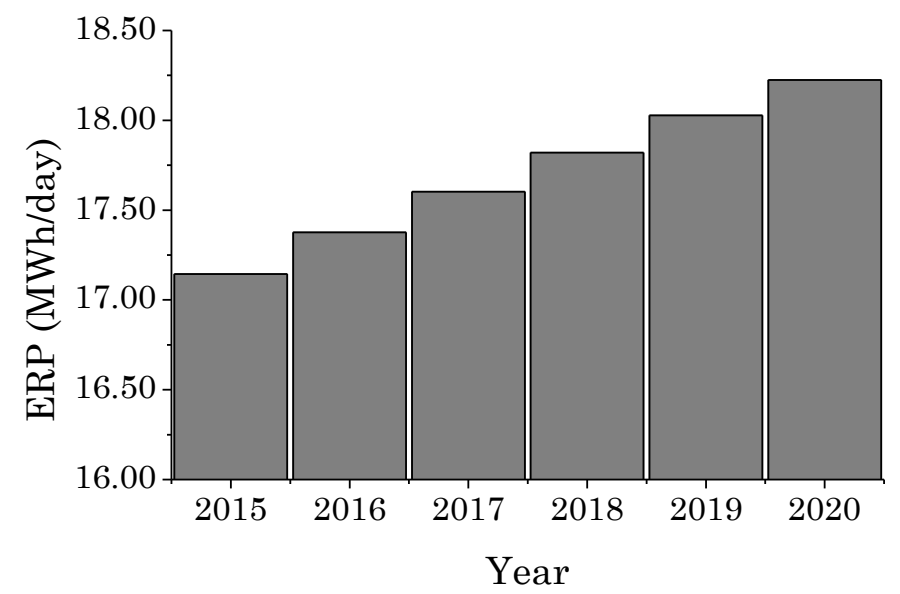

Fig. 9. Electrical energy production from anaerobic digestion in Pasto. Source: Authors.

\section{FURTHER WORK RECOMMENDATIONS}

Future work and research may consider an environmental analysis that measures the amount of greenhouse gases avoided every year thanks to technologies such as anaerobic digestion and incineration.

Furthermore, carbon, SOx and NOx emissions produced by incineration plants could be evaluated, as well as the amount of ferrous and recyclable material that can be recovered at waste storage facilities to be commercialized and thus obtain more economic benefits.

The authors suggest a chemical characterization of waste for a subsequent feasi-

\section{CONCLUSIONS}

This work considered urban solid waste as a potential source of renewable energy in three study cases in Colombia. For that purpose, a method was proposed to select three municipalities based on their demographic features.

In this case, Guayatá ( $\mathrm{UP}=2.94)$, Andes $(\mathrm{UP}=1.02)$ and Pasto $(\mathrm{UP}=0.2)$ were chosen because of their rural/urban population ratio, number of inhabitants and available 
information in their Waste Management Plans.

The population growth projection by DANE shows that the Municipalities of Pasto and Andes present an annual rise. Conversely, in the case of Guayatá, a fall in the number of inhabitants is observed over time.

Since ERP depends on the size of the population, the projection of SW production in Andes is expected to increase in the long term.

Because of the low production of waste in Guayatá, technologies such as incineration are not technically viable.

These results indicate that more energy is generated from incineration than from anaerobic digestion, which is mainly due to the fact that the latter uses organic waste only.

Nevertheless, both technologies provide an alternative to eliminate SW and, if applied, they would alleviate the problem of massive use and accumulation of sanitary landfills.

\section{REFERENCES}

[1] ONU, "La situación demográfica en el mundo," New York, New York, USA, 2014.

[2] "El futuro que queremos las ciudades," in RIO+20 Conferencia de las Naciones Unidas sobre el Desarrollo Sostenible, 2012, pp. 2011-2013.

[3] A. U. Zaman and S. Lehmann, "The zero waste index: a performance measurement tool for waste management systems in a 'zero waste city," J. Clean. Prod., vol. 50, pp. 123132, Jul. 2013.

[4] A. U. Zaman, "Measuring waste management performance using the 'Zero Waste Index': the case of Adelaide, Australia," J. Clean. Prod., vol. 66, pp. 407419, Mar. 2014.

[5] C. Ofori-Boateng, K. T. Lee, and M. Mensah, "The prospects of electricity generation from municipal solid waste (MSW) in Ghana: A better waste management option," Fuel Process. Technol., vol. 110, pp. 94-102, Jun. 2013.

[6] Superintendencia de Servicios Públicos
Domiciliarios República de Colombia, "Disposición Final de Residuos Sólidos Informe Nacional," Bogotá D.C., 2015.

[7] G. Arrieta Bernate, Análisis de la Producción de Residuos Sólidos de Pequeños y Grandes Productores en Colombia. Bogotá: Ministerio de Ambiente, Vivienda y Desarrollo Territorial, 2008.

[8] O. Sabalza and O. Villamizar, "Evaluación del potencial energético de los residuos sólidos orgánicos urbanos provenientes de las plazas de mercado y diseño conceptual de una planta de digestión anaerobia para su aprovechamiento industrial en Colombia," Universidad Industrial de Santander, 2009.

[9] Congreso de Colombia, Ley $N^{\circ} 1715$ del 13 de mayo de 2014, no. May. 2014, p. 26.

[10] Environment and Plastics Industry Council (EPIC), "A Review of the Options for the Thermal Treatment of Plastics," Mississauga, Ontario, 2004.

[11] B. Ž. Bajić, S. N. Dodić, D. G. Vučurović, J. M. Dodić, and J. a. Grahovac, "Waste-toenergy status in Serbia," Renew. Sustain. Energy Rev., vol. 50, pp. 1437-1444, Oct. 2015.

[12] E. Autret, F. Berthier, A. Luszezanec, and F. Nicolas, "Incineration of municipal and assimilated wastes in France: Assessment of latest energy and material recovery performances," J. Hazard. Mater., vol. 139, no. 3, pp. 569-574, Jan. 2007.

[13] L. Zheng et al., "Preferential policies promote municipal solid waste (MSW) to energy in China: Current status and prospects," Renew. Sustain. Energy Rev., vol. 36, pp. 135-148, Aug. 2014.

[14] H. M. Zakir Hossain, Q. Hasna Hossain, M. M. Uddin Monir, and M. T. Ahmed, "Municipal solid waste (MSW) as a source of renewable energy in Bangladesh: Revisited," Renew. Sustain. Energy Rev., vol. 39, pp. 3541, Nov. 2014.

[15] T. O. Somorin, S. Adesola, and A. Kolawole, "State-level assessment of the waste-toenergy potential (via incineration) of municipal solid wastes in Nigeria," J. Clean. Prod., vol. 164, pp. 804-815, Oct. 2017.

[16] O. K. M. Ouda, H. M. Cekirge, and S. A. R. Raza, "An assessment of the potential contribution from waste-to-energy facilities to electricity demand in Saudi Arabia," Energy Convers. Manag., vol. 75, pp. 402406, Nov. 2013.

[17] M. Chakraborty, C. Sharma, J. Pandey, and P. K. Gupta, "Assessment of energy generation potentials of MSW in Delhi under different technological options," Energy Convers. Manag., vol. 75, pp. 249-255, Nov. 
2013.

[18] O. K. M. Ouda, S. A. Raza, A. S. Nizami, M. Rehan, R. Al-Waked, and N. E. Korres, "Waste to energy potential: A case study of Saudi Arabia," Renew. Sustain. Energy Rev., vol. 61, pp. 328-340, Aug. 2016.

[19] X. Zhao, G. Jiang, A. Li, and L. Wang, "Economic analysis of waste-to-energy industry in China," Waste Manag., vol. 48, pp. 604-618, Feb. 2016.

[20] K. A. Kalyani and K. K. Pandey, "Waste to energy status in India: A short review," Renew. Sustain. Energy Rev., vol. 31, pp. 113-120, Mar. 2014.

[21] G. V Ramakrishna, "Electricity Generation from Municipal Solid Waste," 2004.

[22] L. Lombardi, E. Carnevale, and A. Corti, "A review of technologies and performances of thermal treatment systems for energy recovery from waste," Waste Manag., vol. 37, pp. 26-44, Mar. 2015.

[23] IPSE, "En Necoclí los residuos de madera se convierten en importante recurso energético," IPSE Prensa Noticias, 2011. [Online]. Available: http://www.ipse.gov.co/transparencia-yacceso-a-informacion-publica/informacion-deinteres2/noticias/446-en-necocli-los-residuosde-madera-se-convierten-en-importanterecurso-energetico. [Accessed: 23-Jan-2018].

[24] F. C. Luz et al., "Techno-economic analysis of municipal solid waste gasification for electricity generation in Brazil," Energy Convers. Manag., vol. 103, pp. 321-337, Oct. 2015.

[25] I. Kayes and a H. Tehzeeb, "Waste to energy: A lucrative alternative," in 2009 1st International Conference on the Developements in Renewable Energy Technology (ICDRET), 2009, pp. 1-4.

[26] C. H. Coimbra-Araújo et al., "Brazilian case study for biogas energy: Production of electric power, heat and automotive energy in condominiums of agroenergy," Renew. Sustain. Energy Rev., vol. 40, pp. 826-839, Dec. 2014.

[27] GICON, "Valorización energética de los residuos a través de tratamientos biológicos tecnología de biogás," in 1aConferencia panamericana - Waste to Energy 2016, 2016, pp. 41-50.

[28] S. E. Mbuligwe and G. R. Kassenga, "Feasibility and strategies for anaerobic digestion of solid waste for energy production in Dar es Salaam city, Tanzania," Resour. Conserv. Recycl., vol. 42, no. 2, pp. 183-203, Sep. 2004.

[29] J. Jiang, J. Sui, S. Wu, Y. Yang, and L. Wang, "Prospects of anaerobic digestion technology in China," Tsinghua Sci. Technol., vol. 12, no. 4, pp. 435-440, Aug. 2007.

[30] U. Di Matteo, B. Nastasi, A. Albo, and D. Astiaso Garcia, "Energy Contribution of OFMSW (Organic Fraction of Municipal Solid Waste) to Energy-Environmental Sustainability in Urban Areas at Small Scale," Energies, vol. 10, no. 2, p. 229, Feb. 2017.

[31] M. M. V. Leme, M. H. Rocha, E. E. S. Lora, O. J. Venturini, B. M. Lopes, and C. H. Ferreira, "Techno-economic analysis and environmental impact assessment of energy recovery from Municipal Solid Waste (MSW) in Brazil," Resour. Conserv. Recycl., vol. 87, pp. 8-20, Jun. 2014.

[32] X. Hao, H. Yang, and G. Zhang, "Trigeneration: A new way for landfill gas utilization and its feasibility in Hong Kong," Energy Policy, vol. 36, no. 10, pp. 3662-3673, Oct. 2008.

[33] R. Mambeli Barros, G. L. Tiago Filho, and T. R. da Silva, "The electric energy potential of landfill biogas in Brazil," Energy Policy, vol. 65, pp. 150-164, Feb. 2014.

[34] S. S. Mustafa, S. S.Mustafa, and A. H. Mutlag, "Kirkuk municipal waste to electrical energy," Int. J. Electr. Power Energy Syst., vol. 44, no. 1, pp. 506-513, Jan. 2013.

[35] Q. Aguilar-Virgen, P. Taboada-González, and S. Ojeda-Benítez, "Analysis of the feasibility of the recovery of landfill gas: a case study of Mexico," J. Clean. Prod., vol. 79, pp. 53-60, Sep. 2014.

[36] K. M. N. Islam, "Municipal solid waste to energy generation: An approach for enhancing climate co-benefits in the urban areas of Bangladesh," Renew. Sustain. Energy Rev., vol. 81, pp. 2472-2486, Jan. 2018.

[37] J. Prieto and E. C. Luengas Pinzón, "La Ley orgánica de ordenamiento territorial, como instrumento para la integración del ordenamiento territorial y ambiental," Revista gestión integral en ingeniería neogranadina, Bogotá D.C., Colombia, p. 17, Dec-2011.

[38] Congreso de Colombia, Ley 388 del 18 de Julio. 1997, p. 79.

[39] G. J. Posada Hernandez, "Agrupación de municipios colombianos según características de ruralidad," Universidad Nacional de Colombia, 2010.

[40] O. K. M. Ouda, S. a. Raza, R. Al-Waked, J. F. Al-Asad, and A.-S. Nizami, "Waste-to-energy potential in the Western Province of Saudi Arabia," J. King Saud Univ. - Eng. Sci., vol. 
29, no. 3, pp. 212-220, Jul. 2017.

[41] O. F. Corredor Becerra, "Evaluación del potencial energético de la biomasa residual proveniente de cultivos energéticos," 2008.

[42] A. Gómez, J. Zubizarreta, M. Rodrigues, C. Dopazo, and N. Fueyo, "Potential and cost of electricity generation from human and animal waste in Spain," Renew. Energy, vol. 35, no. 2, pp. 498-505, Feb. 2010.

[43] N. J. Themelis, M. Elena, D. Barriga, P. Estevez, and M. G. Velasco, Guidebook for the application of waste to energy technologies in Latin America and the Caribbean. New York, N.Y.: Earth Engineering Center, Columbia University, 2013.

[44] B. Leckner, "Process aspects in combustion and gasification Waste-to-Energy (WtE) units," Waste Manag., vol. 37, pp. 13-25, Mar. 2015.

[45] Grupo EPM, "Gestión y valorización de residuos sólidos urbanos (RSU). Evaluación de nuevas oportunidades de negocio," in $1^{a}$ Conferencia panamericana - Waste to Energy 2016, 2016, p. 25.

[46] J. D. Murphy and K. McCarthy, "The optimal production of biogas for use as a transport fuel in Ireland," Renew. Energy, vol. 30, no. 14, pp. 2111-2127, Nov. 2005.

[47] Municipio de Guayatá, "Plan de Gestión Integral de Residuos Sólidos PGIRS Municipio de Guayatá," Guayatá," SLIDEX.TIPS, 2015. [Online]. Available: https://slidex.tips/queue/plan-de-gestionintegral-de-residuos-solidos-pgirs-municipiode-guayata-boyaca-c?\&queue_id=. $1 \& \mathrm{v}=1524775150 \& \mathrm{u}=\mathrm{MTkwLjI0OC} 4 \mathrm{yOC} 4 \mathrm{x}$ $\mathrm{MzE}=$.

[48] I. C. Arroyave Tobón, "Plan De Gestión De Residuos Sólidos Municipio De Andes." pp. 43-45, 2005.

[49] R. Delgado Guerrero, Plan de Gestión Integral de Residuos Sólidos Municipio de
Pasto. San Juan de Pasto, Nariño, Colombia: EMAS de Pasto, 2007.

[50] A. Estrada Wiechers, "Pre-feasibility study of using the Circulating Fluid Bed ( CFB ) waste-to-energy technology in Mexico City," Columbia University, 2015.

[51] M. Rafiq Khan and H. Tanveer, "Production of thermoelectric power from Solid Waste of Urban Lahore," in 2011 International Conference \& Utility Exhibition on Power and Energy Systems: Issues and Prospects for Asia (ICUE), 2011, pp. 1-11.

[52] S. A. S. Abd Kadir, C.-Y. Yin, M. Rosli Sulaiman, X. Chen, and M. El-Harbawi, "Incineration of municipal solid waste in Malaysia: Salient issues, policies and wasteto-energy initiatives," Renew. Sustain. Energy Rev., vol. 24, pp. 181-186, Aug. 2013.

[53] J. A. Poletto Filho, "Viabilidade Energética E Econômica Da Incineração De Resíduo Sólido Urbano Considerando a Segregação Para Reciclagem. Universidade Estadual Paulista," Universidad Estadual Paulista, 2008.

[54] New York City Economic Development Corporation, Hunts Point Anaerobic Digestion Feasibility Study. New York: DSM Environmental Services, Inc, R.S. Lynch \& Company, 2010.

[55] F. F. Palacio Suárez, "Estudio de la prefactibilidad de generar energía eléctrica utilizando como fuente primaria la cacota del café que se produce en la región de Cajamarca para satisfacer las necesidades de una finca que consume $1 \mathrm{MWh}$ por mes," Universidad de la Salle, 2007.

[56] J. Cadena, S. Pérez, and J. Mora, "Análisis de viabilidad financiera de una central de generación de energía eléctrica a partir del biogás de vertedero," Sci. Tech. Año XVI, vol. 51, pp. 1-7, 2012. 